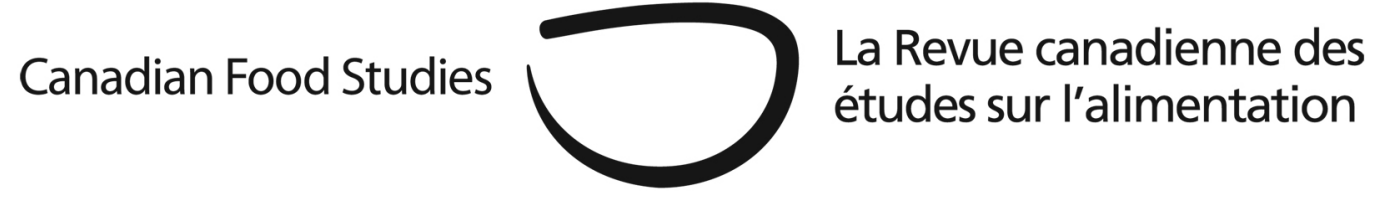

Original Research Article

\title{
Student food insecurity at the University of Manitoba
}

\author{
Meghan Entza ${ }^{a}$ Joyce Slater ${ }^{b}$, and Annette Aurélie Desmarais ${ }^{c^{*}}$ \\ aResearch assistant, University of Manitoba, Department of Sociology \\ ${ }^{b}$ Assistant professor, Human Nutritional Sciences, University of Manitoba \\ 'Canada Research Chair in Human Rights, Social Justice and Food Sovereignty, University of \\ Manitoba
}

\begin{abstract}
While rates of food insecurity among various sectors of the Canadian population are well documented, food insecurity among post-secondary students, as a particularly vulnerable population, has emerged in recent years as an area of research. Based on a survey of 548 students in the 2015/16 school year, this exploratory study examines the extent of food insecurity among undergraduate and graduate students at the University of Manitoba. Our study revealed that 35.3 percent of survey respondents faced food insecurity according to a 6-item survey. Of these students, 23.5 percent experienced moderate food insecurity, while 11.8 percent were deemed to be severely food insecure. Using chi-square tests and regression analysis, we compare these rates with various demographic indicators to assess which students appear to be at greater risk of food insecurity, factors contributing to food insecurity, and its effect on their student experience, their health, and their lives in general. In contemplating funding for post-secondary institutions and increases in tuition fees, provincial governments need to consider how this will affect student food insecurity.
\end{abstract}

Keywords: food insecurity; food security; university students; Manitoba; Canada; student debt; student health; survey 


\section{Introduction}

Life as a student should not be this hard, education should not be this hard to obtain ${ }^{1}$

According to the UN Food and Agriculture Organization, food security is defined as "when all people, at all times, have physical and economic access to sufficient, safe and nutritious food to meet their dietary needs and food preferences for an active and healthy life” (FAO, 2006). Alternatively, food insecurity at the household level is experienced when people are economically unable to purchase sufficient quantities of food or balanced meals that they need (Davis \& Tarasuk, 1994; Tarasuk, Mitchell, and Dachner, 2014). The nature and prevalence of food insecurity is a growing concern in Canada and other affluent nations. The 2012 UN Special Rapporteur on the Right to Food Mission to Canada helped shed light on various dimensions of the growing problem of food insecurity in the country (De Schutter, 2012). While evidence has suggested high and increasing rates of food insecurity among certain populations of university students (such as campus food bank users or students receiving financial aid) (Abbott, Abbott, Aird, Weyman, Lethbridge, \& Lei, 2014; Farahbakhsh, Ball, Farmer, Maximova, Hanbazaza, \& Willows, 2015; Meldrum and Willows, 2006; Nugent, 2011; Willows \& Au, 2006), quantitative investigation of food insecurity among post-secondary students in Canada has more recently emerged. Numerous factors contribute to student food insecurity, but most notable are the increasing financial burdens faced by post-secondary students (Farahbakhsh et. al., 2015; Nugent, 2011; Cummings, 2015; Silverthorn, 2016).

This exploratory article contributes to the emerging research on food insecurity at Canadian post-secondary institutions by examining the extent of, and factors related to, food insecurity affecting a population of students at the University of Manitoba. To set the context, we begin by presenting some general data on, and contributing factors of, food insecurity within the general population in Canada and Manitoba. This is followed by a brief exploration of studies that have examined food insecurity at Canadian campuses.

\section{Context}

\section{Food insecurity in Canada and Manitoba}

According to national surveys, rates of food insecurity in Canada are rising. As of 2014, 12 percent of Canadians are affected, which is an increase from 7.7 percent in 2007/08 (Tarasuk, Mitchell, \& Dachner, 2014). Within the young adult population, or those 20-34 years old, the rate of food insecurity was 11.6 percent as of 2012/13 (Statistics Canada, 2013).

\footnotetext{
${ }^{1}$ Excerpt from student participants' comments submitted as part of the food security survey
} 
In Canada, low income is the most reliable predictor of food insecurity (Tarasuk, Mitchell \& Dachner, 2014). Over one million Canadians receive social assistance, not including the 780,000 individuals on disability. Of these Canadian whose primary source of income is social assistance, 60.9 percent are food insecure; for those receiving employment insurance or workers compensation, their rates are 35.6 percent (Tarasuk, Mitchell \& Dachner, 2014). Rates of food insecurity and food bank use are disproportionately higher among certain populations, including single-parent families headed by women, and households with children under the age of 18 (Tarasuk, Mitchell, \& Dachner, 2014). Indigenous Canadians are also over-represented, with rates of food insecurity among non-reserve Aboriginal populations of 25.7 percent in 2014 (Tarasuk, Mitchell, \& Dachner, 2014). This statistic is likely significantly lower than rates of food insecurity on First Nations Reserves and in Northern Indigenous communities, which are monitored differently through other measures of Indigenous food insecurity in Canada (Huet, Rosol, \& Egeland, 2012; FNIGC, 2012; Egeland Pacey, Cao, \& Sobol, 2010).

In Manitoba, current statistics regarding food insecurity are lacking due to the province's omission of measures of food security in the 2014 Canadian Community Health Survey. However, in 2012 provincial household food insecurity affected 12.1 percent of Manitobans, up from 10 percent in 2010, but down from 12.4 percent in 2007 (Tarasuk, Mitchell, \& Dachner, 2014). Much like the rest of the country, low income has been identified as the primary reason for food insecurity in Manitoba (Wiebe \& Distasio, 2016). In 2015, Manitoba had the highest national rates of food bank use, distributing emergency relief to 63,791 individuals, which represents a 58 percent increase compared to 2008/09 (Pegg, 2008). Almost 5 percent (4.93 percent) of Manitobans resorted to food banks, in comparison to the 2.83 percent national average (McCracken, 2016). It is important to note, however, that this is an under-representation of food insecurity, as studies show that only one-third of food insecure Canadians seek food bank services (Farahbakhsh, 2015).

\section{Food insecurity at Canadian universities}

The prevalence and severity of food insecurity among university students across Canada is beginning to receive attention. Recently, researchers initiated a number of studies on several campuses, to assess the prevalence of food insecurity among various university student populations. Selected questions from the Household Food Security Status Module (HFSSM) of the Canadian Community Health Survey (CCHS) were the primary tool used in these studies for assessing rates of food insecurity. The results of these studies, aggregated by a national organization called Meal Exchange ${ }^{2}$, show that the average rate of food insecurity among

\footnotetext{
2 The results of five studies conducted in 2015/16 by independent researchers at five Canadian post-secondary institutions were aggregated by Meal Exchange in the report Hungry for Knowledge: Assessing the prevalence of student food insecurity on five Canadian campuses. See http://www.mealexchange.com/ for information on Meal Exchange.
} 
students at five major Canadian Universities is 39.2 percent. The results of Meal Exchange’s report are summarized below (Table 1).

Table 1: Rates of student food insecurity at 5 major Canadian universities

\begin{tabular}{|l|c|c|c|}
\hline Institution & $\begin{array}{l}\text { Percent of students } \\
\text { moderately food } \\
\text { insecure }\end{array}$ & $\begin{array}{l}\text { Percent of students } \\
\text { severely food insecure }\end{array}$ & $\begin{array}{l}\text { Percent of students who } \\
\text { are food insecure }\end{array}$ \\
\hline Dalhousie University & 36.9 & 9.1 & 46 \\
\hline Lakehead University & 31.2 & 14.7 & 45.9 \\
\hline Ryerson University & 30.9 & 8 & 38.9 \\
\hline Brock University & 29.2 & 7.3 & 36.5 \\
\hline University of Calgary & 25.7 & 4.3 & 30 \\
\hline
\end{tabular}

Preliminary results from unpublished studies from two additional Canadian universities show that 38.1 percent of students at the University of Acadia and 28.6 percent of students at the University of Saskatchewan were food insecure (Frank, Engler-Stringer, Power, \& Pulsifer, 2015). Methodologies used in these two studies are closely comparable to the Canadian Community Health Survey, and therefore less comparable to the surveys tailored specifically to post-secondary students, employed at the University of Manitoba, and the five institutions listed above where some CCHS questions were used, but in a slightly modified form.

Prior to the studies undertaken by Frank et. al. (2015) and Silverthorn (2016), food security in Canadian post-secondary students was assessed mainly through food bank use. Since the 1990s, the number of food banks on university campuses has continued to rise; for example, as of 2011 there were over 70 food banks located on university campuses, up from 56 in 2006 (Gordon, 2011). In recent years, the University of Alberta, the University of Calgary, the University of Ottawa and Ryerson University have all cited increases in campus food bank use (Nugent, 2011; CBC News, 2012). ${ }^{3}$

The effects of food insecurity are far reaching. Food insecurity among post-secondary students in Canada has been linked to higher levels of stress and increased rates of depression and mental disorders (Stuff, Casey, Szeto, Gossett, Robbins, Simpson, Connell, \& Bogle, 2004). Among students surveyed at five Canadian universities in 2016, physical and mental health were identified as the primary factors negatively affected by students' experiences with food insecurity (Silverthorn, 2016). Additionally, students identified (in descending order) that their social life, grades, class participation, and extra-curricular activities were the next most negatively affected factors of their personal and academic lives (Silverthorn, 2016). Among

\footnotetext{
${ }^{3}$ Similar trends of food insecurity have been recorded on university campuses internationally. Rates of 39\% to 59\% of student populations have been identified as food insecure at post-secondary institutions in the United States, and Australia (Chaparro et. al., 2009; Hughes et. al., 2011; Patton-Lopez et al., 2014, Gorman, 2014).
} 
elementary students, food insecurity has been associated with lower math and reading scores, in addition to decreased memory (Cady, 2014). Among adult populations, food security can have negative effects on individuals' sense of community and belonging (Willows, Veugelers, Raine, \& Kuhle, 2011).

In addition to scoring lower in measures of mental health, food insecure individuals in Canada specifically have been cited as exhibiting nutritional inadequacies, including deficiencies in protein, vitamin A, B-6, and B-12, thiamin, riboflavin, folate, phosphorous, and zinc (Kirkpatrick \& Tarasuk, 2008). Likely as a result of these deficiencies, and additional negative health repercussions, food insecurity in Canada has been associated with higher use of public health care services, including inpatient hospital care, emergency medical services, and prescription drug use. Rates of public health care usage among food insecure households are double, compared with food secure households (32 percent vs 16 percent), indicating a disproportionate burden on the Canadian healthcare systems (Tarasuk, Cheng, de Oliveira, Dachner, Gundersen, \& Kurdyak, 2015).

\section{Methods}

\section{Participants}

The University of Manitoba is the largest post-secondary institution in the province of Manitoba, and is located in the capital city, Winnipeg. In 2016 when the study was conducted, total enrollment was 28,804, with 3,654 graduate level students, or 13 percent. Of the total student population, 54 percent was female, and 46 percent was male (University of Manitoba, 2016). To engage student participants, the survey used census-style sampling and was sent out to all undergraduate and graduate students through e-mails from the University of Manitoba Student Union, various individual student groups including the Graduate Student Association, and sustainable food initiatives on campus.

\section{Data collection}

The online survey was conducted in January and February 2016, and administered by Survey Monkey. The survey was open to all students over the age of 18 . The study was approved by the University of Manitoba Research Ethics Board, and participants provided consent through the survey interface. The survey included 33 questions, and rates of student food insecurity were assessed using six questions designed for Canadian post-secondary student populations (Silverthorn, 2016). These questions are listed in Table 2. The survey also included two questions that directly asked students to rate their own food insecurity. 
Other questions regarding specific demographic populations were modeled on unpublished surveys administered at Acadia University and the University of Saskatchewan. These demographic questions asked students to identify their student status, sex, age, living arrangement, primary source of income, aboriginal and immigration status, marital status, and whether or not they payed rent, or had children or dependents. Two questions about selfidentified mental and physical health were asked, based on the Canadian Community Health Survey. Questions pertaining to students' experiences with, and coping mechanisms for food insecurity were adapted from questionnaires administered at several other Canadian postsecondary institutions ${ }^{4}$ (Silverthorn, 2016). These questions are identified in Table 3 . The survey included two questions asking students to identify what factors contribute most to their food insecurity, and the primary areas of their lives affected by their food insecurity. These questions, and the selection of responses provided to the survey participants, are identified in Table 4. Finally, the survey included an open-ended question that allowed students to provide additional comments pertaining to their experiences with food insecurity. The response rate, based on the University of Manitoba's student population of 28, 809, was 1.9 percent, or 548 students. Rates of student food insecurity were assessed using the six questions listed in Table 2.

Table 2: Questions used to assess moderate and severe food insecurity

1. I/we worried whether my/our food would run out before I got money to buy more.

2. The food that I bought just didn’t last, and I didn’t have money to buy more.

3. I/we couldn't afford to eat meals with a variety of foods, or a number of different kinds of foods, according to what I/we prefer.

4. I had to sacrifice buying healthy (nutritious or diversified) foods in order to afford enough food.

5. I/ we skipped meals because there wasn't enough money to buy food

6. I/we did not eat for a whole day because there wasn't enough money for food

Table 3: Questions used to assess students' coping mechanisms against food insecurity

I/we went to a food bank, hunger relief or soup kitchen service (such as Winnipeg Harvest, Siloam Mission, Lighthouse Mission, Agape Table ${ }^{5}$, etc.) because I did not have the money to buy enough food. Was this often true, sometimes true, or never true in the past 12 months?

I thought about going to a food bank or hunger relief program but was too embarrassed to actually go. Was this often true, sometimes true, or never true in the past 12 months?

I had to engage in unconventional ways of obtaining my food such as "dumpster diving" or stealing in order to have enough to eat. Was this often true, sometimes true, or never true in the past 12 months?

If employed, how has working affected your studies?

\footnotetext{
${ }^{4}$ Drafts of surveys administered by researchers from these institutions were shared through private correspondence from the researchers themselves.

${ }^{5}$ These are examples of well-known hunger relief programs and food banks in Winnipeg, Manitoba.
} 
Table 4: Questions assessing students’ experiences with food insecurity

\begin{tabular}{|c|c|}
\hline $\begin{array}{l}\text { 1. If you have experienced } \\
\text { periods of food insecurity, } \\
\text { what do you believe } \\
\text { contributes to your food } \\
\text { insecurity? } \\
\text { Select all that apply. }\end{array}$ & $\begin{array}{l}\text { - } \text { I have not experienced food insecurity in the last } 12 \text { months } \\
\text { - Tuition fees } \\
\text { - Housing costs } \\
\text { - Transportation expenses } \\
\text { - } \text { Physical accessibility to food } \\
\text { - Cost of food } \\
\text { - Inadequate income supports (student loans \& grants) } \\
\text { - Limited time to prepare food } \\
\text { - Limited knowledge and skills to prepare food } \\
\text { - Limited facilities and equipment to prepare food } \\
\text { - } \text { Other }\end{array}$ \\
\hline $\begin{array}{l}\text { 2. If you identified as being food } \\
\text { insecure, what areas of your } \\
\text { life have been negatively } \\
\text { impacted as a result of your } \\
\text { food insecurity? } \\
\text { Select all that apply. }\end{array}$ & $\begin{array}{ll}\text { - } & \text { I have not experienced food insecurity in thee last } 12 \text { months } \\
\text { - } & \text { Physical health } \\
\text { - } & \text { Sental health } \\
\text { - } & \text { Parenting responsibilities } \\
\text { - } & \text { Grades } \\
\text { - } & \text { Class participation } \\
\text { - } & \text { Extra-curricular activities } \\
\text { - } & \text { Other }\end{array}$ \\
\hline
\end{tabular}

\section{Data analysis}

Based on the methodology used in similar studies of student food insecurity (Silverthorn, 2016), we categorized respondents into three categories of food insecurity depending on their answers to the six questions in Table 2. Students who responded positively ("often" or "sometimes true”) to 0 - 1 of the six questions were assessed to be food secure, whereas students who responded positively to 2-4 of the questions were assessed as moderately food insecure, and students who responded positively to 5-6 questions were categorized as severely food insecure.

Descriptive and univariate analyses were applied to the survey data. Chi-square tests of statistical significance were used in order to assess which demographic groups were at greater risk of food insecurity, and univariate regressions were employed to assess the odd ratios of these demographic populations experiencing food insecurity. The statistical tests were conducted based on moderate, severe and overall rates of food insecurity. The total number of food insecure students within each population was calculated based on the total number of students assessed to be either moderately or severely food insecure. The data was analyzed using SPSS software, and the findings of these analyses, as well as discussion of results are summarized below. 


\section{Findings}

As represented in Table 3, the majority of 548 students who completed the survey were female, younger than 25, and studying at the undergraduate level. The majority of students were also single, and lived without any children or dependents. Among respondents, just over two-thirds identified as having fair to poor mental health, with 24.3 percent reporting fair to poor physical health. Within this category, 19.9 percent reported having fair physical health, and 4.4 percent assessed their physical health as poor. Mental health was reported to be fair by 23.5 percent of students, while 12.3 percent assessed their mental health as poor. The majority of students were employed, and cited employment or loans as their primary source of income. Just under half of students reported living alone or with a roommate or spouse, while just over half pay rent, mortgage, or residence fees for their accommodation.

This study found that 35.3 percent of the students surveyed were food insecure. Of these students, 23.5 percent faced moderate food insecurity, while 11.8 percent experienced severe food insecurity. The proportion of students assessed to be food insecure based on this study's methodology was considerably higher than the number of students who self-identified as food insecure, based on the provided FAO definition of the term provided to them (13.2 percent of survey respondents).

Among those who participated in the survey, several demographic groups were found to be more food insecure than others. Almost three-quarters of Indigenous students were assessed to be food insecure. As represented in Table 4, 42.1 percent of Indigenous students experienced moderate food insecurity, and almost a third were severely food insecure. Of the total number of students found to be food insecure, Indigenous students are between five and ten times more likely to report food insecurity than non-Indigenous students. Almost one-third of newcomers to Canada and exchange students were food insecure, and of these, over one-quarter were severely food insecure.

Students’ primary source of income was also relevant to students' experiences with food insecurity. Severely food insecure students were almost five times more likely to be on student or bank loans. Almost 60 percent of these students were food insecure. Comparably, 34.3 percent of students who were employed, and 30 percent of students whose income came from scholarships, grants, or parents were found to be food insecure.

Students who experienced food insecurity were significantly more likely to experience poor to fair mental and physical health than those who were food secure. Among students with self-identified fair to poor mental health, almost half faced food insecurity (48.5 percent), while among students with fair to poor physical health, 53.9 percent were food insecure.

Slightly more than one-fifth of students identified financial barriers that affected their access to food. For example, they experienced periods when buying enough food was sacrificed to pay for tuition or textbooks, or because there was no longer enough money. 
Table 3: Socio-demographic characteristics of study participants

\begin{tabular}{|c|c|c|c|}
\hline \multicolumn{2}{|c|}{ Total survey population $\mathrm{N}=548$} & \multirow{2}{*}{$\begin{array}{ll}\mathbf{N} \\
123\end{array}$} & \multirow{2}{*}{\begin{tabular}{r|} 
percent \\
27.6
\end{tabular}} \\
\hline $\operatorname{Sex}^{\mathrm{a}}$ & Male & & \\
\hline & Female & 323 & 72.4 \\
\hline \multirow{2}{*}{ Age $^{b}$} & $17-24$ & 357 & 77.6 \\
\hline & over 24 & 103 & 22.4 \\
\hline \multirow[t]{4}{*}{ Student Status ${ }^{b}$} & Undergraduate & 396 & 86 \\
\hline & Graduate & 64 & 14 \\
\hline & Part-time & 48 & 10.4 \\
\hline & Full-time & 412 & 89.6 \\
\hline \multirow[t]{2}{*}{ Mental Health $^{\mathrm{C}}$} & Good-Excellent & 304 & 64.3 \\
\hline & Poor-Fair & 169 & 35.7 \\
\hline \multirow{2}{*}{$\begin{array}{l}\text { Physical } \\
\text { Health }^{\mathrm{c}}\end{array}$} & Good-Excellent & 358 & 75.7 \\
\hline & Poor-Fair & 115 & 24.3 \\
\hline \multirow[t]{3}{*}{ Identity $^{\mathrm{d}}$} & Indigenous Canadian & 19 & 4.7 \\
\hline & Newcomer to Canada or Exchange Student & 51 & 12.5 \\
\hline & $\begin{array}{l}\text { Non-Indigenous Manitoban, or student from another } \\
\text { province }\end{array}$ & 338 & 82.8 \\
\hline \multirow[t]{2}{*}{ Marital Status ${ }^{e}$} & Single & 372 & 81.2 \\
\hline & $\begin{array}{l}\text { Married, Common Law, Widowed, Divorced or } \\
\text { Separated, Other }\end{array}$ & 86 & 18.8 \\
\hline \multirow{2}{*}{$\begin{array}{l}\text { Children or } \\
\text { Dependents }^{\mathrm{f}}\end{array}$} & Has children or dependents & 26 & 5.7 \\
\hline & Does not have children or dependents & 430 & 94.3 \\
\hline \multirow{2}{*}{$\begin{array}{l}\text { Employment } \\
\text { Status }^{\text {b }}\end{array}$} & Employed & 322 & 70 \\
\hline & Not employed & 138 & 30 \\
\hline \multirow{3}{*}{$\begin{array}{l}\text { Effects of } \\
\text { Employment } \\
\text { on Studies }^{\mathrm{g}}\end{array}$} & Negatively & 164 & 49.8 \\
\hline & Not at all & 115 & 35 \\
\hline & Positively & 50 & 15.2 \\
\hline \multirow{3}{*}{$\begin{array}{l}\text { Primary } \\
\text { Source of } \\
\text { Income }^{f}\end{array}$} & Provincial/federal or bank loans & 59 & 13 \\
\hline & $\begin{array}{l}\text { Scholarships/Grants, Savings or RESPs, Parents or } \\
\text { Guardians, do not have an income, "other" }\end{array}$ & 193 & 42.3 \\
\hline & Employed full or part-time & 204 & 44.7 \\
\hline \multirow[t]{2}{*}{$\begin{array}{l}\text { Payment on } \\
\text { Residence }^{\mathrm{h}}\end{array}$} & $\begin{array}{l}\text { Do pay rental fees, mortgage, residence fees for } \\
\text { accommodation }\end{array}$ & 249 & 54.5 \\
\hline & Do not pay fees for accommodation & 208 & 45.5 \\
\hline \multirow{4}{*}{$\begin{array}{l}\text { Nature of } \\
\text { Residence }^{\mathrm{h}}\end{array}$} & Alone or with a roommate & 140 & 30.6 \\
\hline & $\begin{array}{l}\text { With spouse/ common law partner, with or without } \\
\text { children }\end{array}$ & 62 & 13.6 \\
\hline & In campus residence, with or without access to kitchen & 19 & 4.2 \\
\hline & With parents/ guardians, or extended family & 236 & 51.6 \\
\hline
\end{tabular}

${ }^{\mathrm{a}} \mathrm{N}=446,{ }^{\mathrm{b}} \mathrm{N}=460,{ }^{\mathrm{c}} \mathrm{N}=473,{ }^{\mathrm{d}} \mathrm{N}=408,{ }^{\mathrm{e}} \mathrm{N}=458,{ }^{\mathrm{f}} \mathrm{N}=456,{ }^{\mathrm{g}} \mathrm{N}=329,{ }^{\mathrm{h}} \mathrm{N}=457$ 
Table 4: Frequency of study participants with various levels of food insecurity, compared with demographic characteristics

\begin{tabular}{|c|c|c|c|c|c|c|c|}
\hline \multicolumn{2}{|c|}{$\mathrm{FI}=$ food insecurity $\mathrm{N}=248$} & \multicolumn{2}{|c|}{ Moderate FI } & \multicolumn{2}{|c|}{ Severe FI } & \multicolumn{2}{|c|}{ Mod + Sev FI } \\
\hline & & percent & OR & percent & OR & percent & OR \\
\hline \multicolumn{2}{|l|}{ Total $^{\mathrm{a}}$} & 23.5 & & 11.8 & & 35.3 & \\
\hline \multirow[t]{2}{*}{$\operatorname{Sex}^{\mathrm{a}}$} & Female & 25.7 & 1.4 & 10.2 & - & 35.9 & 1.2 \\
\hline & ${ }^{\mathrm{b}}$ Male & 19.5 & - & 12.2 & 1.1 & 31.7 & - \\
\hline \multirow[t]{2}{*}{ Age $^{b}$} & $17-24$ & 23.2 & - & 9.8 & - & 33.1 & - \\
\hline & $25-60+$ & 25.2 & 1.2 & 15.5 & 1.8 & 40.8 & 1.4 \\
\hline \multirow{4}{*}{$\begin{array}{l}\text { Student } \\
\text { Status }^{\mathrm{b}}\end{array}$} & Undergraduate* & 23.7 & 1.0 & 11.4 & 1.3 & 35.1 & 1.1 \\
\hline & Graduate & 23.4 & - & 9.4 & - & 32.8 & - \\
\hline & Part-time* & 25 & 1.1 & 12.5 & 1.2 & 37.5 & 1.1 \\
\hline & Full-time & 23.5 & - & 10.9 & - & 34.5 & - \\
\hline \multirow[t]{3}{*}{ Identity $^{\mathrm{d}}$} & $\begin{array}{l}\text { Non-Indigenous Manitoban, or student } \\
\text { from another province* }\end{array}$ & 21.9 & - & 8 & - & 29.9 & - \\
\hline & $\begin{array}{l}\text { a Newcomer to Canada or Exchange } \\
\text { Student }\end{array}$ & 31.4 & 2.4 & 27.5 & 5.9 & 58.8 & 3.4 \\
\hline & ${ }^{\text {a} I n d i g e n o u s ~ C a n a d i a n ~}$ & 42.1 & 5.1 & 31.6 & 10. & 73.7 & 6.6 \\
\hline \multirow[t]{2}{*}{ Marital Status $^{\mathrm{e}}$} & Single* & 22.6 & - & 11.8 & 1.2 & 34.4 & - \\
\hline & $\begin{array}{l}\text { Married, Common Law, Widowed, } \\
\text { Divorced or Separated, Other }\end{array}$ & 25.4 & 1.1 & 10.4 & - & 35.8 & 1.1 \\
\hline \multirow{2}{*}{$\begin{array}{l}\text { Children or } \\
\text { Dependents }\end{array}$} & None* & 23.3 & - & 10.9 & - & 34.2 & - \\
\hline & ${ }^{b}$ Has children or dependents & 34.6 & 2 & 15.4 & 1.9 & 50 & 1.9 \\
\hline \multirow{2}{*}{$\begin{array}{l}\text { Mental } \\
\text { Health }^{c}\end{array}$} & Good-Excellent* & 19.7 & - & 7.9 & - & 27.6 & - \\
\hline & ${ }^{\mathbf{a}}$ Poor-Fair & 30.8 & 2.2 & 17.8 & 3.2 & 48.5 & 2.9 \\
\hline \multirow{2}{*}{$\begin{array}{l}\text { Physical } \\
\text { Health }^{c}\end{array}$} & Good-Excellent* & 21.2 & - & 7.8 & - & 29.1 & - \\
\hline & ${ }^{\mathrm{a} P o o r-F a i r}$ & 31.3 & 2.3 & 22.6 & 4.5 & 53.9 & 2.5 \\
\hline \multirow{2}{*}{$\begin{array}{l}\text { Employment } \\
\text { status }^{\text {b }}\end{array}$} & Employed* & 25.5 & 1.5 & 11.5 & 1.3 & 37 & 1.1 \\
\hline & Not employed & 19.6 & 1.3 & 10.1 & - & 29.7 & - \\
\hline \multirow[t]{3}{*}{$\begin{array}{l}\text { Primary } \\
\text { Source of } \\
\text { Income }^{\mathrm{f}}\end{array}$} & $\begin{array}{l}\text { Scholarships/Grants, Savings or RESPs, } \\
\text { Parents or Guardians, do not have an } \\
\text { income, "other"* }\end{array}$ & 21.2 & - & 7.8 & - & 29 & - \\
\hline & Employed full or part-time & 24 & 1.2 & 10.8 & 1.5 & 34.8 & 1.3 \\
\hline & 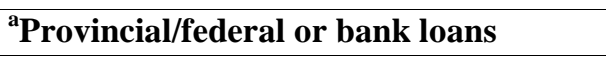 & 32.2 & 2.4 & 23.7 & 4.9 & 55.9 & 3.1 \\
\hline \multirow{2}{*}{$\begin{array}{l}\text { Payment on } \\
\text { Residence }^{\mathrm{h}}\end{array}$} & Do not pay fees for accommodation* & 15.9 & - & 2.4 & - & 18.3 & - \\
\hline & $\begin{array}{l}\text { a'Does pay rental fees, mortgage, } \\
\text { residence fees for accommodation }\end{array}$ & 30.5 & 3.1 & 18.5 & 12.3 & 49.0 & 4.3 \\
\hline \multirow{4}{*}{$\begin{array}{l}\text { Nature of } \\
\text { Residence }^{\text {h }}\end{array}$} & With parents/ guardians, extended family* & 18.2 & - & 5.1 & - & 23.3 & - \\
\hline & $\begin{array}{l}\text { alone, with a roommate or in } \\
\text { precarious arrangements }\end{array}$ & 31.4 & 3 & 24.3 & 8.3 & 55.7 & 4.1 \\
\hline & With a spouse/common law, with children & 29.1 & 1.8 & 4.8 & 1.1 & 33.9 & 1.7 \\
\hline & Residence with or without kitchen access & 21.1 & 1.3 & 10.5 & 2.3 & 31.6 & 1.5 \\
\hline
\end{tabular}

${ }^{\mathrm{a}} \mathrm{N}=446,{ }^{\mathrm{b}} \mathrm{N}=460,{ }^{\mathrm{c}} \mathrm{N}=473,{ }^{\mathrm{d}} \mathrm{N}=408,{ }^{\mathrm{e}} \mathrm{N}=458,{ }^{\mathrm{f}} \mathrm{N}=456,{ }^{\mathrm{g}} \mathrm{N}=329,{ }^{\mathrm{h}} \mathrm{N}=457$

$(*=$ reference category, Bolded $=$ statistical significance at $\mathrm{P}>.05$ ) 
Figure 1: Contributors to food insecurity

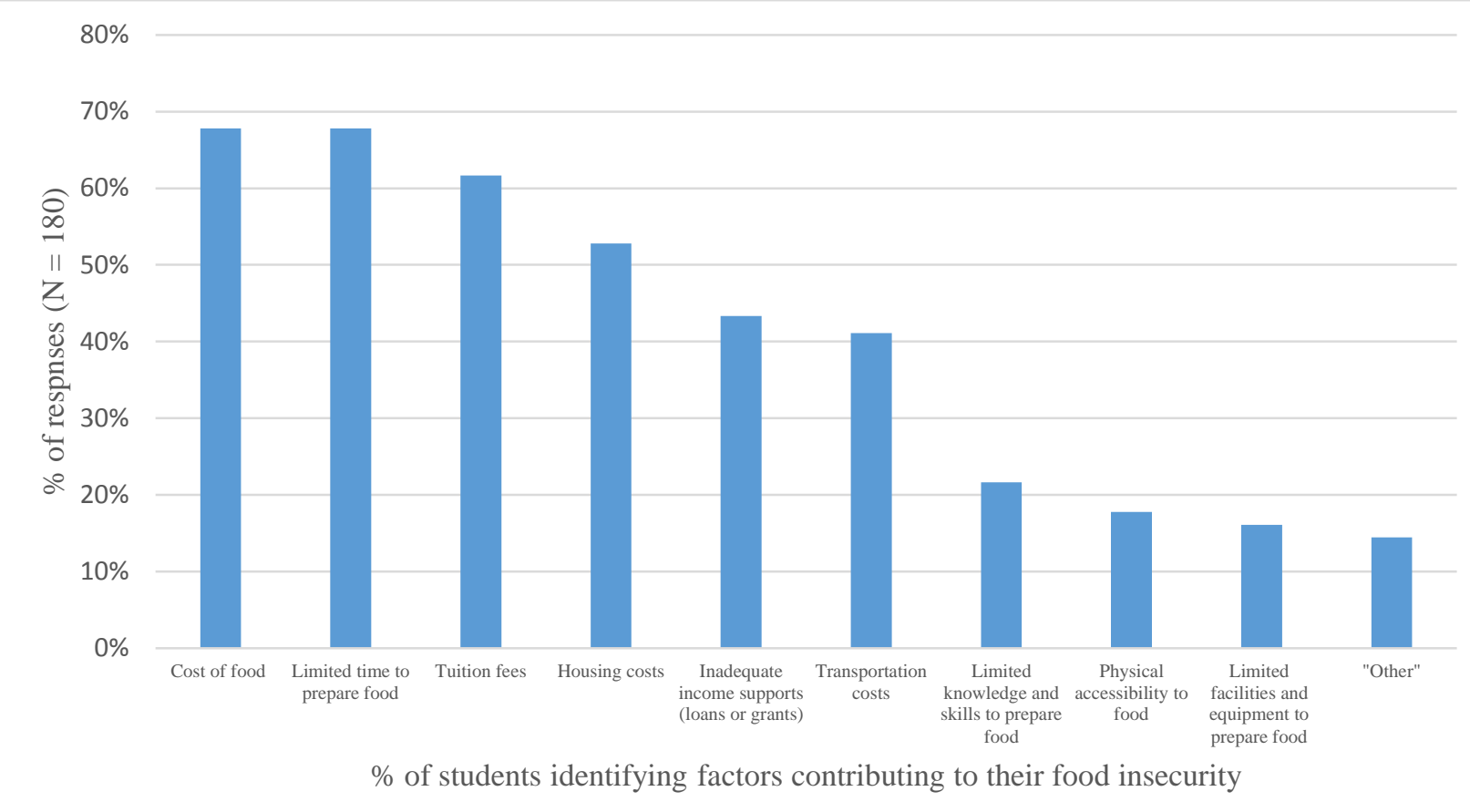

Figure 1 shows the major contributing factors to food insecurity identified by survey participants in their responses to question A (identified in Table 4), based on the selection of answers provided to them. High cost of food was identified by one-fifth of all respondents, and $70 \%$ of respondents who identified as food-insecure, as the primary barrier affecting their access to food. In the written responses to the survey, students identified that they experienced periods when buying enough food was sacrificed to pay for tuition or textbooks, or because there was no longer enough money. Limited time was the second most cited factor. Apart from these, financial barriers such as tuition fees, housing costs, and inadequate financial support in the form of loans or grants were also significant. These responses correlate with the univariate findings that identify higher rates of food insecurity among students who live independently, and therefore bear a larger proportion of their own food and residence costs.

Both mental and physical health were found to be the most significant areas of life most impacted by food insecurity (Figure 2). Almost two-thirds cited grades as being negatively affected. This was followed closely by students' extracurricular activities, and social lives. In response to increased financial burdens, students use a variety of coping mechanisms to sustain themselves. In answering the open-ended question located at the end of the survey, several students remarked on their need to work in addition to taking classes in order to meet their financial obligations. One student in this survey stated, "It's sad that I cannot feed myself after work[ing] 40 hours a week." Another student remarked on the effects that additional work has on their studies, stating that "something has to take a back seat and for me that is school so I have enough money to live comfortably." Another responded that "If I have to work more, then I take 
less courses, it's that simple in my opinion.” One student commented on the time constraints caused by their multiple commitments, "studying really limits the time I have to buy groceries and cook, as well as exercise and my social life.” The same student also reflected on the difficulties this creates in finding the time to prepare meals, "I enjoy cooking but most days I rely on frozen dinners and quick fixes because I don't have the time to cook things, and am very stressed."

Some students engaged in unconventional coping mechanisms, such as food bank use and stealing. Questions pertaining to coping mechanisms are described in Table 3. Despite the 11.9 percent of severely food insecure students, in total less than 4 percent of the population of respondents, and less than 10 percent of students who were food insecure identified as having used a food bank or hunger relief program in order to have enough to eat. Additionally, less than 4 percent of students identified as having to engage in unconventional coping mechanisms, such as "dumpster diving” or stealing. One student shared that they relied on credit cards in order to purchase food in times when they lacked cash, but added, "We don't want to go into a lot of debt, but we want our child to be healthy and we hope this is only temporary."

Figure 2: Areas of life negatively affected by food insecurity

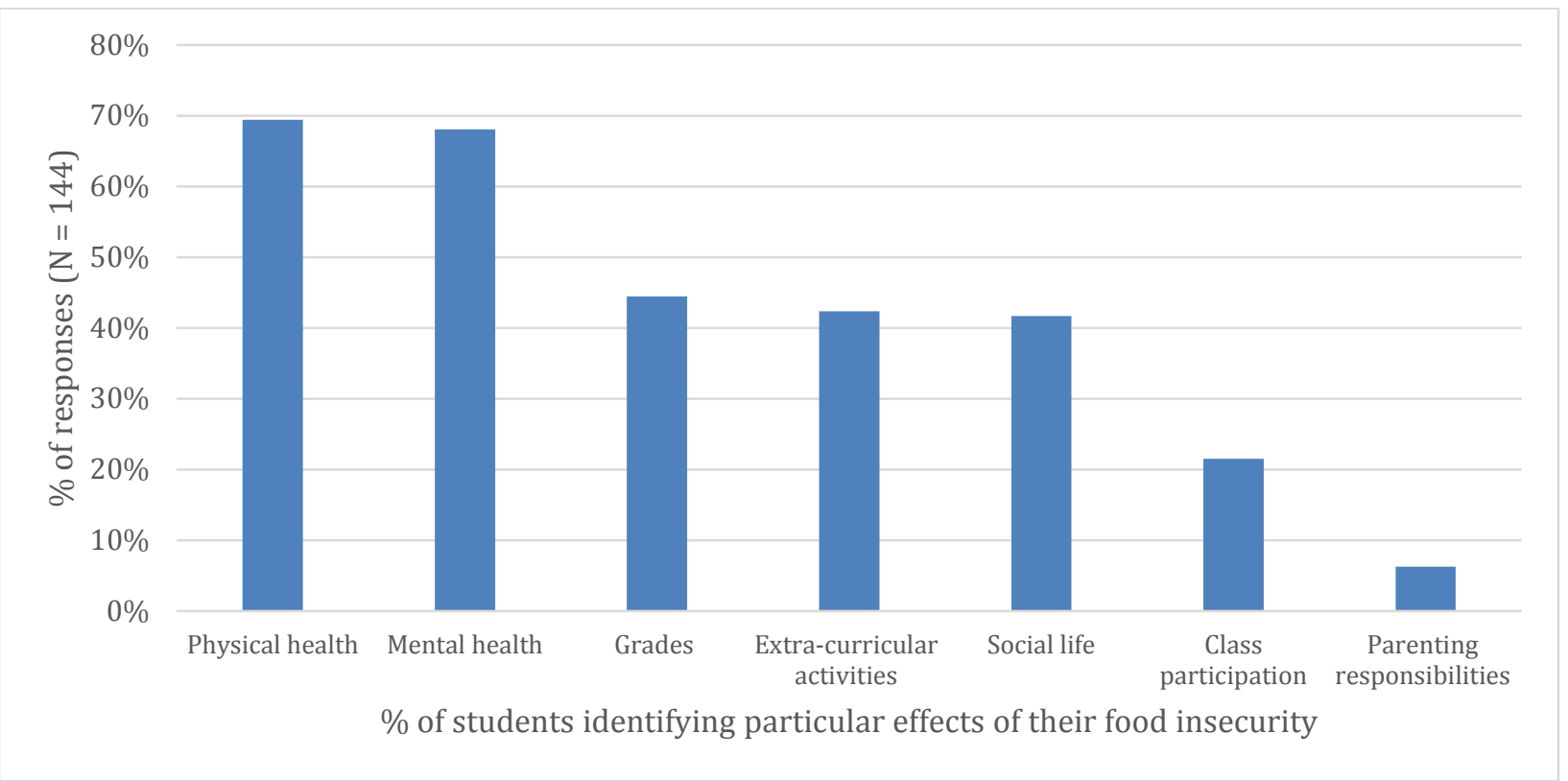

\section{Discussion}

Food insecurity is a reality for more than one-third of students surveyed at the University of Manitoba. Almost one-quarter of them experience moderate food insecurity, while more than one in ten surveyed were severely food insecure. 
In comparison with other Canadian post-secondary institutions where 39.4 percent of students experience food insecurity (Silverthorn, 2016), rates at the University of Manitoba were slightly lower. However, while the University of Manitoba has the lowest number of moderately food insecure students, at $\mathbf{1 1 . 8}$ percent it has the second highest rate of severely food insecure students, next to Lakehead University in Northern Ontario. Several factors could explain why the overall rate of food insecurity among students at the University of Manitoba might be comparatively lower than other provinces such Nova Scotia and Ontario.

Manitoba boasts relatively low costs of housing and tuition, as well as different student demographics. While transportation and food costs remain slightly above national averages, average housing costs in Manitoba are slightly lower than provinces such as Saskatchewan and Alberta. The cost of shelter was most recently assessed at \$14,481 per year in Manitoba, significantly lower than the $\$ 17,160$ national average, and when compared to provinces such as British Columbia, Ontario, and Alberta which average \$18,497, \$19,409, and \$20,676 respectively (Statistics Canada, 2016a). On a national scale, post-secondary tuition fees in Manitoba are also comparatively low. In relation to the $\$ 6,373$ national yearly average paid by domestic students across the country, students in Manitoba paid an average of $\$ 4,058$ in the 2016/17 academic year (Statistics Canada, 2016b). Largely due to the 2011 provincial legislation tying tuition fees to inflation, Manitoban students pay the third lowest tuition fees in the country, after Quebec and Newfoundland and Labrador (Statistics Canada, 2016b).

\section{Financial factors}

Low income and financial obligations (tuition fees and loans) contributed significantly to the food insecurity of participants, despite Manitoba's low tuition and housing costs. Many rely on student loans. Although Manitoba students work fewer hours to cover the cost of a year's tuition fees (366 hours of work at minimum wage are required to pay for the cost of tuition, compared to the national average of 570 hours), this figure still marks a 100 percent increase compared to 1975 (Moore, 2014). Studies of Canadian university student populations, and specifically campus food bank users, cite lack of financial resources, food costs, transportation costs, and high cost of living as primary causes of food bank use (Nugent, 2011; Stewin, 2013; Frank et. al., 2015; Meldrum \& Willows, 2006; House, Su, \& Levy-Milne, 2016; Silverthorn, 2016).

According to Meal Exchange's Hungry for Knowledge report (2016), students ranked food and housing costs to be the largest contributors to food insecurity, followed by inadequate income supports in the form of student loans and grants, and limited facilities to prepare food (Silverthorn, 2016).

Since the 1990s, tuition has tripled in Canada, and by 2011 total payments owed by students in loans to the federal government reached \$15 billion (Burley \& Awad, 2015). In 2014, average student debt in Canada was \$28,295 (Burley \& Awad, 2015). In Ontario, students under the loan program have been reported to have annual shortfalls of $\$ 1,232$ for women, and $\$ 1,712$ for men (Crisp, 2015). High food bank usage has also been recorded among international 
students across Canada, who pay significantly higher tuition fees (Farahbakhsh et. al, 2015; Stewin, 2013).

Among those students who were employed, the stresses of working were identified by half of survey participants, who reported that their employment had negative effects on their studies. This statistic compares with other studies that have found that the need to work in addition to attending classes negatively affects students' academic performance (Prairie Research Associates, 2011; Motte \& Schwartz, 2009). Today, the effects of balancing work and school are affecting a larger proportion of post-secondary students. Whereas one in four students worked while attending University 35 years ago, in 2010 the proportion is just under one in two (Marshall, 2010).

Living at home with parents or guardians was protective against food insecurity, likely due to having family or others in the household pay all or most food and housing costs. One student commented, "If I was not living at home and was on my own for all expenses I would think it would be almost impossible to be food secure.” Winnipeg has one of the highest proportion of young adults staying at home in the country (43.3 percent), behind Toronto and Vancouver (Statistics Canada, 2015b). Given that the majority of respondents were 20-29 years of age or younger, the University of Manitoba's rates of food security may be buffered by a tendency among students to live at home longer.

\section{Indigenous, newcomer and exchange students}

Certain groups of students appeared to be more vulnerable to food insecurity. Indigenous students were significantly more likely to experience food insecurity than those who are nonIndigenous. The Canadian Community Health Survey administered in 2014 assesses food insecurity among off-reserve aboriginal populations at 25.7 percent, however, alternative measures of Indigenous food insecurity in Canada record rates significantly higher. Indigenous Canadians are more vulnerable to risk factors for food insecurity such as extreme poverty, single-motherhood, living in rental accommodation, and increased rates of dependence on social services (Willows, Veugelers, \& Kuhle, 2009).

Newcomer and exchange students were also significantly more likely to experience food insecurity compared to other non-Indigenous students. Other campus food security studies have attributed high international student fees and a lack of culturally appropriate food options as contributing factors (Stewin, 2013). International students studying at many Canadian universities are required to pay significantly higher fees than Canadian citizens and Permanent Residents. For example, in the 2015/16 school year at the University of Manitoba, international students paid \$2,228 more annually than domestic students for one 6-credit hour or full-year science course, and international students in the law program pay just under 2.5 times the domestic rate (University of Manitoba, 2016). In the comment section of our survey, one student suggested that support be provided to international students by "reduc[ing] tuition fees for international students so we can live a better, healthier life. Physiological needs are important. 
Perhaps the school can donate food items on monthly basis to needy international students.” One Newcomer who acknowledged they had been in Canada for 14 months claimed they had never experienced food insecurity, however, they stated "I can't afford to buy extra food or stuff I want to taste with the money I get from [my] part-time job...I can only afford to buy the necessary food which satisfies me."

\section{Effects on health}

Study participants who experienced food insecurity stated that deterioration of mental and physical health were among the aspects of their lives most affected. This is consistent with observations from the general population, where chronic disease and mental disorders have been associated with food insecurity (Stuff et. al., 2004; Willows et. al., 2011, Tarasuk et. al., 2013). Regarding mental health, a 2013 study of the general Canadian population found that among severely food insecure individuals, 47.1 percent of women and 23.4 percent of men cited anxiety or mood disorders (Tarasuk et. al., 2013). One student from this study wrote that, "not having enough to eat has definitely affected my concentration in class.” Another commented that not having enough time to provide for their food needs "is having a big impact on my health, and my mental health. I have found myself in many periods of depression throughout my time in University."

Students' experiences with food insecurity can also constrain young peoples’ opportunities to engage in individual or collective non-academic, social outlets. According to our survey, students' experiences with food insecurity negatively affected both grades and extracurricular activities, where the stress of succeeding in school affected students' participation in physical extra-curricular activities and their mental health. Therefore, food insecurity could impact students' overall mental and physical health by affecting students' lives in a variety of ways, such as nutritional and caloric deficiencies or negative influences on students' grades and concentration, while at the same time restricting students' opportunities and for extra-curricular activities and participation in social outlets.

\section{Limitations of study}

The first limitation of our study is the relatively small sample size. While there were several statistically significant observations made based on the population of survey respondents, the findings may not reflect the realities of all students at the University of Manitoba. Secondly, due to the use of a specific survey tailored to post-secondary students, comparisons made to rates of food insecurity among the general population, calculated through specific questions used in the Canadian Community Health Survey, should be made with caution. Lastly, alternative factors may have affected the accuracy of the survey results. These factors could include poor food skills, and, unwillingness or disinterest in eating diverse and healthy foods. The limitations identified by this exploratory study suggest that more work needs to be done in order to 
quantitatively and qualitatively capture the extent of food security on university campuses, as well as to ensure that further research can be equipped with the appropriate tools necessary to comprehensively define and investigate the relatively new concept of food insecurity.

\section{Conclusion}

This study contributes a uniquely Manitoban perspective to the emerging area of research on post-secondary student food insecurity, reinforces the need to assess the barriers faced by students, and addresses the implications for students' health and wellbeing. The respondents reported high rates of food insecurity that appear to be having a negative impact on their overall health, and in some cases, their academic performance. This exploratory study highlights the need to conduct further research into the prevalence, nature, causes, and effects of food insecurity at the University of Manitoba. It also delineates the need for a standardized assessment method for all Canadian universities to allow for ongoing surveillance and comparison.

Student food insecurity has implications for the future of the Manitoba and Canadian work force, as well as public health care expenditure. The main predetermining factor in food insecurity is inadequate finances due to housing, transport, food, and tuition costs. This disproportionately affects certain groups, such as newcomer and Indigenous students, who experience significantly higher rates of food insecurity. It is up to university administrators, student services, and provincial policy-makers to take action to ensure affected students have the financial and other resources necessary to succeed in their studies.

The federal Liberal government's focus on post-secondary student issues was reflected in their 2016 budget through increased grant funding as an alternative to loans. However, these policies currently only impact undergraduate students; policies to benefit graduate students are yet unknown (Snider, 2016). As of now, Manitoba post-secondary students pay comparatively low prices for tuition and living expenses. However, in 2015/16 tuition rates did rise in Manitoba by 1.9 percent, compared to 0 percent in provinces like Newfoundland, Alberta, and New Brunswick where fees were frozen (Statistics Canada 2016b). Media reports indicate that the newly elected Conservative provincial government is considering removing the cap on tuition fees for post-secondary institutions (Martin 2016). Should this occur, student food insecurity could rise, unless loans and other financial aid to students were increased and made more available.

Acknowledgement: This research was made possible with funding from the Canada Research Chairs program. Our thanks to the University of Manitoba's Office of Sustainability, University of Manitoba Student's Union, and the University of Manitoba's Graduate Student's Association for their assistance in making the survey possible. We also are grateful to the students who took the time to complete the survey. 


\section{References}

Abbott, B., Abbott, J., Aird, B., Weyman, C., Lethbridge, D., \& Lei, L. (2014). Food Security among Dalhousie Students. Retreived from https://www.dal.ca/content/dam/dalhousie/pdf/science/environmental-scienceprogram/ENVS percent203502 percent20projects/2015/Foodbank.pdf

American College Health Association (2013). National College Health Assessment II: Canadian Reference Group Data Report, September 11. Retrieved from http://www.cacuss.ca/_Library/documents/NCHAII_WEB_SPRING_2013_CANADIAN_REFERENCE_GROUP_DATA_REPORT.pdf

Burley, G., \& Awad, A. (2015). The Impact of Student Debt. Canadian Federation of Students. Retreived from www.cfs-fcee.ca

Cady, C. L. (2014) Food insecurity as a student issue. Journal of College and Character, 15(4), 265-272. http://dx.doi.org/10.1515/jcc-2014-0031

CBC News (2012). 1 in 10 University of Ottawa students uses food bank. CBC News, (November). Retrieved from http://www.cbc.ca/news/canada/ottawa/1-in-10-university-ofottawa-students-uses-food-bank-1.1195942

Chaparro, M. P., Zaghloul, S.S., Holck, P., \& Dobbs, J. (2009). Food insecurity prevalence among college students at the University of Hawai'i at Mānoa. Public Health Nutrition, 12(11), 2097-2103. http://doi.org/10.1017/S1368980009990735

Crisp, S. (2015) Ryerson's Good Food Centre releases first Hunger Report. Ryersonian.ca (March). Retrieved from http://ryersonian.ca/ryersons-good-food-centre-releases-firsthunger-report/

Davis, B., \& Tarasuk, V. (1994). Hunger in Canada. Agriculture and Human Values, 11(50). 5057. http://doi.org/10.1007/BF01530416

Egeland, G., Pacey, A., Cao, Z., \& Sobol, I. (2010). Food insecurity among Inuit preschoolers: Nunavut inuit Child Health Survey, 2007-2008. Canadian Medical Association Journal 183(2). 243-248. http://doi.org10.1503/cmaj.091297

Eicher-Miller, H. A., Mason, A. C., Weaver C. M., McCabe, G. P., \& Boushey, C. J. (2009). Food insecurity is associated with iron deficiency anemia in US, 90(5). 1358-1371. http://doi.org/10.3945/ajcn.2009.27886.1358

Farahbakhsh, J., Ball, G. D. C., Farmer, A. P., Maximova, K., Hanbazaza, M., \& Willows, N. D. (2015). How do student clients of a university-based food bank cope with food insecurity? Canadian Journal of Dietetic Practice and Research, 76(4), 200-203. http://doi.org/10.3148/cjdpr-2015-020 
First Nations Information Governance Centre (FNIGC). (2012). First Nations Regional Health Survey (RHS) 2008/10. Ottawa: FNIGC.

Food and Agriculture Organization (FAO). (2006). Policy Brief: Food security, Issue 2 FAO Agriculture and Development Economics (June). Retreived from http://www.fao.org/forestry/131280e6f36f27e0091055bec28ebe830f46b3.pdf

Frank, L., Engler-Stringer, R., Power, E., \& Pulsifer, B. (2015, March). Feeding Academic Appetites?: Exploring food insecurity among Canadian university students. Conference Poster presented at the Canadian Food Studies Conference, Ottawa, ON.

Gordon, A. (2011). Need for campus food banks on the rise. Toronto Star (September). Retrieved from https://www.thestar.com/life/2011/09/19/need_for_campus_food_banks_on_the_rise.html

Gorman, A. (2014). Food Insecurity Prevalence among College Students at Kent State University (Masters Dissertation). Ohio Link. Available from from https://etd.ohiolink.edu/ http://doi.org/10.1017/CBO9781107415324.004

Health Canada. (2012). Household Food Insecurity in Canada in 2007-2008: Key Statistics and Graphics. Food and Nutrition Surveillence. Retrieved from http://www.hc-sc.gc.ca/fnan/surveill/nutrition/commun/insecurit/key-stats-cles-2007-2008-eng.php.

House, J., Su, J., \& Levy-Milne, R. (2006). Definitions of Healthy Eating Among University Students. Canadian Journal of Dietetic Practice and Research, 67(1), 14-18.

Huet, C, Rosol, R., Egeland, G.M. (2012). The prevelence of food insecurity is high and diet quality poor in Inuit communities. Journal of Nutrition, 142(3), 541-547. http://doi.org10.3945/jn.111.149278

Hughes, R., Serebryanikova, I., Donaldson, K., \& Leveritt, M. (2011). Student food insecurity: The skeleton in the university closet. Nutrition and Dietetics, 68(1), 27-32. http://doi.org/10.1111/j.1747-0080.2010.01496

Kirkpatrick, S. I., \& Tarasuk, V. (2008). Food Insecurity Is Associated with Nutrient Inadequacies among Canadian Adults, The Journal of Nutrition Community and International Nutrition (December), 138, 604-612.

Marshall, K. (2010). Employment patterns of postsecondary students. Perspectives on Labour and Income, 11(9), 5-17. http://doi.org/75-001

Martin, N. (2016). Province hinting at university, college tuition hikes. Winnipeg Free Press, October 4, Available at http://www.winnipegfreepress.com/local/province-hinting-atuniversity-college-tuition-hikes-395900961.html

McCracken, M. (2016). Fight food insecurity with income, Molly McCracken writes. CBC News, (February). Retreived from http://www.cbc.ca/news/canada/manitoba/fight-food-insecuritywith-income-molly-mccracken-writes-1.3430124 
Meldrum, L. A., \& Willows, N. D. (2006). Food insecurity in university students receiving financial aid. Canadian Jourbal of Dietetic Practice and Research, 691(6), 43-46.

Moore, H. (2014). Soaring tuition costs force students to work more hours: Analysis. CBC News, April. Retrieved from http://www.cbc.ca/news/canada/manitoba/soaring-tuition-costs-forcestudents-to-work-more-hours-analysis-1.2610095

Motte, A., \& Schwartz, S. (2009). Are Student Employment and Academic Success Linked? Millennium Research Note \#9, 1-15. Retreived from https://library.carleton.ca/sites/default/files/find/data/surveys/pdf_files/millennium_200904-15_rn-9_en.pdf

Nugent, M. A. (2011). Journeys to the food bank: Exploring the experience of food insecurity among postsecondary students. (Masters Dissertation). University of Lethbridge Institutional Repository. Available from https://www.uleth.ca/dspace

Patton-Lopez, M. M., Lopez-Cevallos, D. F., Cancel-Tirado, D. I., \& Vazquez, L. (2014). Prevalence and correlates of food insecurity among students attending a midsize rural university in Oregon. Journal of Nutrition Education and Behavior, 46(3), 209-214. http://doi.org/10.1016/j.jneb.2013.10.007

Pegg, S. (2008). Hunger Count 2008: A Comprehensive Report on Hunger and Food Bank Use in Canada, 1-36. Retrieved from www.foodbankscanada.ca

Praire Research Associates (2011). 2011 Undergraduate University Student Survey. Prepared for: the Candian University Survey Consortium. June $23^{\text {rd }}$, 2011. Retrieved from http://www.pra.ca/resources/pages/files/Reports/Education\%20Training/CUSC_2011_UG_ MasterReport.pdf

Silverthorn, D. (2016) Hungry for Knowledge: Assessing the prevalence of student food insecurity on five Canadian campuses. Toronto: Meal Exchange. Retrieved from: http://mealexchange.com

Snider, P. (2016). Canada's Student Aid Programs : Making Money Less of an Object, 4(5), 5759. Retrieved from http://www.policymagazine.ca/pdf/21/PolicyMagazineSeptemberOctober-2016WebReady.pdf.

Statistics Canada. (2013). Household food insecurity, by age group and sex, Canada, provinces, territories, and health regions (2013 boundaries) and peer groups, CANSIM 105-0547. Date modified December 2013. Retrieved from http://www5.statcan.gc.ca/cansim/a26?lang=eng\&id=1050547

Statistics Canada. (2015a). Food insecurity in Canada. Health at a Glance, Catalogue no. 82624-X. Date modified 2015-05-34. Retrieved from http://www.statcan.gc.ca/pub/82-624x/2015001/article/14138-eng.pdf 
Statistics Canada. (2015b). Living arrangements of young adults aged 20-29. Census in Brief Series, Catalogue no. 98-312-X2011003. Date modified December 2015. Retrieved from https://www12.statcan.gc.ca/census-recensement/2011/as-sa/98-312-x/98-312-x2011001eng.cfm

Statistics Canada. (2015c). University Tuition Fees, 2015/2016. The Daily, Catalogue no. 11001-X. Date modified September 2015. Retrieved from http://www.statcan.gc.ca/dailyquotidien/150909/dq150909b-eng.htm

Statistics Canada. (2016a). Table 203-0021 - Survey of household spending (SHS), household spending, Canada, regions and provinces, annual (dollars), CANSIM 203-0021. Date modified April 2016. Retrieved from http://www5.statcan.gc.ca/cansim/a26?lang=eng\&id=2030021

Statistics Canada. (2016b). Undergraduate tuition fees, Canadian students, by selected standard geographic areas and by field of study annual. CANSIM 477-0121. Date modified September 2016. Retrieved from http://www5.statcan.gc.ca/cansim/a26?lang=eng\&retrLang=eng\&id=4770121\&\&pattern=\& stByVal=1\&p1=1\&p2=-1\&tabMode=dataTable\&csid=

Stewin, E. (2013). An Exploration of Food Security and Identity Among International Students Studying in Guelph and Windsor, Ontario, Canada. (Masters Dissertation). Retreived from https://atrium2.lib.uoguelph.ca

Stuff, J. E., Casey, P. H., Szeto, K. L., Gossett, J. M., Robbins, J.M., Simpson, P. M., Connell, C., \& Bogle, M. L. (2004). Household Food Insecurity Is Associated with Adult Health Status. Community and International Nutrition, (January) 134, 2330-2335

Tarasuk, V., Mitchell, A., McLaren, L., \& McIntyre, L. (2013). Chronic physical and mental health conditions among adults may increase vulnerabilty to household food insecurity. The Journal of Nutrition, 143, 1785-1793, doi: 0.3945/jn.113.178483

Tarasuk, V., Mitchell, A., \& Dachner, N. (2014). Household Food Insecurity in Canada, 2014. Toronto: Research to identify policy options to reduce food insecurity (PROOF). Retrieved from http://proof.utoronto.ca

Tarasuk, V. S., Cheng, J., de Oliveira, C., Dachner, N., Gundersen, C., \& Kurdyak, P. (2015). Association between household food insecurity and annual health care costs. Canadian Medical Association Journal, 187(14), 29-36. http://doi.org/10.1503/cmaj.150644

Prairie Research Associates. (2011). Canadian University Survey Consortium - 2011 Undergraduate University Student Survey - Master Report, 1-76. Retrieved from http://www.cusc-ccreu.ca/publications/CUSC_2011_UG_MasterReport.pdf

UN Human Rights Council. (2012). Report of the Special Rapporteur on the right to food: Mission to Canada, December 2012, A/HRC/22/50/Add.1. Retreived from http://www.srfood.org/images/stories/pdf/officialreports/20121224_canadafinal_en.pdf. 
University of Manitoba. (2016). Tuition, Endowment and Student Organization Fees: 20162017. Retrieved from http://umanitoba.ca/student/records/fees/Undergraduate_Tuition.html

Wiebe, K., \& Distadio, J. (2016). Confronting the Illusion: Developing a method to identify food mirages and food deserts in Winnipeg. University of Winnipeg Intitute of Urban Studies InBrief Series (June). Retrieved from http://uwinnipeg.ca/ius/docs/reports/2016-06-22-foodsecurity-in-brief.pdf

Willows, N. D., \& Au, V. (2006). Nutritional quality and price of university food bank hampers. Canadian Journal of Dietetic Practice and Research, 67(2), 104-107. http://doi.org/10.3148/67.2.2006.104

Willows, N. D., Veugelers, P., Raine, K., \& Kuhle, S. (2009). Prevalence and sociodemographic risk factors related to household food security in Aboriginal peoples in Canada. Public Health Nutrition, 12(8), 1150-6. http://doi.org/10.1017/S1368980008004345

Willows, N. D., Veugelers, P., Raine, K., \& Kuhle, S. (2011). Associations between household food insecurity and health outcomes in the Aboriginal population (excluding reserves). Statistics Canada, 22(82) Catalogue no. 82-003-XPE, 15-20. Retrieved from http://www.statcan.gc.ca/pub/82-003-x/2011002/article/11435-eng.htm 